\title{
Shunt Resistance Determination in a Silicon Solar Cell: Effect of Flow Irradiation Energy and Base Thickness
}

\author{
Ousmane Sow ${ }^{1}$, Mamadou Lamine $\mathrm{Ba}^{2}$, Hamet Yoro $\mathrm{Ba}^{2}$, \\ Mohamed Abderrahim Ould El Moujtaba², Youssou Traore ${ }^{3}$, Masse Samba Diop3, \\ Habiboullah Lemrabott², Mamadou Wade ${ }^{3}$, Grégoire Sissoko² \\ ${ }^{1}$ University Institute of Technology, University of Thiès, Thiès, Sénégal \\ ${ }^{2}$ Laboratory of Semiconductors and Solar Energy, Physics Department, Faculty of Science and Technology, University Cheikh \\ Anta Diop, Dakar, Senegal \\ ${ }^{3}$ Ecole Polytechnique de Thiès, Thiès, Sénégal \\ Email: gsissoko@yahoo.com
}

How to cite this paper: Sow, O., Ba, M.L., Ba, H.Y., El Moujtaba, M.A.O., Traore, Y., Diop, M.S., Lemrabott, H., Wade, M. and Sissoko, G. (2019) Shunt Resistance Determination in a Silicon Solar Cell: Effect of Flow Irradiation Energy and Base Thickness. Journal of Electromagnetic Analysis and Applications, 11, 203-216.

https://doi.org/10.4236/jemaa.2019.1112014

Received: October 29, 2019

Accepted: December 2, 2019

Published: December 5, 2019

Copyright $\odot 2019$ by author(s) and Scientific Research Publishing Inc. This work is licensed under the Creative Commons Attribution International License (CC BY 4.0).

http://creativecommons.org/licenses/by/4.0/

\begin{abstract}
The concept of the recombination of the minority carrier's recombination velocity at the junction and in the rear, is used for determination, optimum thickness and then shunt resistance in the base of the silicon solar cell, maintained in steady state and under energy from the irradiation flow of charged particles. Resistance shunt is obtained and modeled through a relationship expressed according to the flow and energy of irradiation imposed on the solar cell.
\end{abstract}

\section{Keywords}

Silicon Solar Cell, Irradiation, Recombination Velocity, Shunt Resistance, Optimum Base Thickness

\section{Introduction}

Shunt resistance is a very important parameter of the equivalent electric model of the solar cell, which induces the leaking current of electrical charges when it is of low value [1]. Thus it limits the electric output current and reduces the efficiency [2] [3] [4]; it then influence solar cells industrial manufacturing processes [5] [6] [7]. Therefore, its determination is the subject of several measurement techniques, especially from electrical current and voltage [8] [9]. Some characterization techniques [10] [11]; generally maintain, the solar cell in steady state, 
under darkness or polychromatic illumination [12] [13] and depending to the model to be used [14] [15]. Others use an electrical or optical signal in modulated frequency, to extract impedance and deduce its components (series [16] and shunt resistances [17] [18], capacitance [19]).

In addition to the experimental conditions of illumination constant or variable [20], there are additional: temperature variations [21], the presence of electromagnetic field [22] [23], its exposure to an irradiation flow of charged particles [24] [25]. These conditions impose a variation in the diffusion coefficient of minority carriers in the base of the solar cell [26]. Manufacturing conditions set the material doping rate $(\mathrm{Nb})$ [27] [28] [29], which itself influences the diffusion coefficient of minority carriers $\mathrm{D}(\mathrm{Nb})$.

Theoretically, the investigation is done by considering the crystallographic aspect i.e., in a one-dimensional (1D) [29] or three-Dimensional (3D) model of space [30]. The latter case takes into account the grain size $(\mathrm{g})$ and the grains boundaries recombination velocity (Sbg), which influence the shunt resistance [31] [32].

Regardless of the model used [33], the recombination rate at the junction ( $x=$ $0)$ and in the rear $(x=H)$ in the base of the solar cell, is taken into account through, respectively the surfaces recombination velocity Sf and Sb [34] [35] [36]. These phenomenological parameters (recombination in the bulk and surfaces), have studied and extracted, with theoretical and experimental methods, keeping the solar cell under steady [37] [38] or dynamic state [39] [40] [41].

In this work, we determine the shunt resistance, of a $\mathrm{n}^{+}-\mathrm{p}-\mathrm{p}^{+}$silicon solar cell, whose base has undergone irradiation of charged particles [42] [43]. Its thickness [44] [45] is taken into account and optimized through the study of the theoretical expression of excess minority carrier recombination velocity in the rear face [46]. Then, using the concept of recombination velocity at the junction initiating the short circuit of the solar cell [47] [48] under steady state, we determine the shunt resistance, for each thickness imposed by the intensity of the irradiation flow of charged particles.

\section{Theoretical Study}

\subsection{Presentation of the Solar Cell}

Figure 1 represents $\mathrm{n}^{+}-\mathrm{p}-\mathrm{p}^{+}$silicon solar cell [29] illuminated by the polychromatic light and under irradiation. The cell consists of a emitter doped in $\left(\mathrm{n}^{+}\right)$, a base doped in (p), a space charge zone where there is an intense field to separate the pairs of electron holes that arrives there, $x$ is the depth in the base of the solar cell measured from the emitter-base junction, called space charge region (SCR) $(x=0)$ to the back side face $(x=H) . H$ is the base thickness, where a back surface field (BSF) is created by help of the $\mathrm{p}^{+}$zone. $k l$ is the damage coefficient while $\phi_{p}$ is the irradiation energy flow.

\subsection{Theory}

When the solar cell is illuminated by a constant polychromatic light, all the 


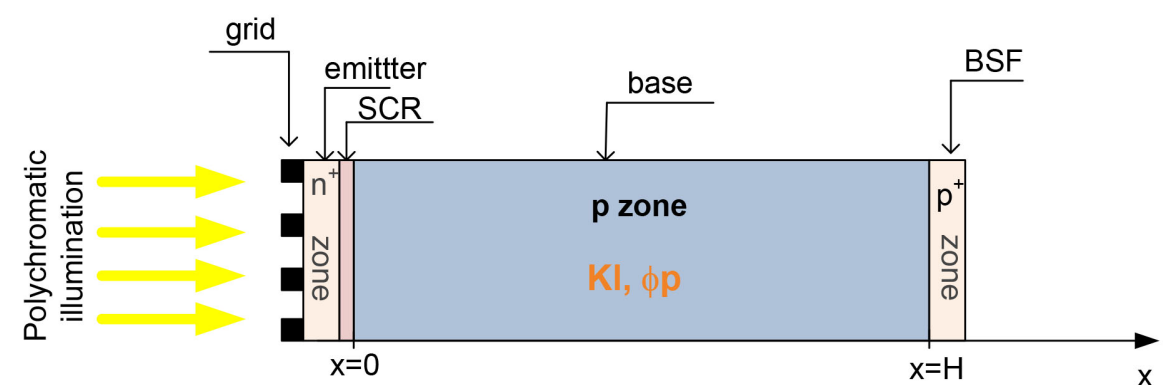

Figure 1. Structure of the silicon solar cell $\left(\mathrm{n}^{+}-\mathrm{p}-\mathrm{p}^{+}\right)$under irradiation.

physical processes that governed the excess minority charge carriers in the base are: photogeneration, diffusion, recombination in the bulk and surfaces. The minority carriers obey to the continuity equation and boundary conditions, expressed by the following Equations ((1), (6) and (7)):

$$
D\left(k l, \phi_{p}\right) \frac{\partial^{2} \delta\left(x, k l, \phi_{p}\right)}{\partial x^{2}}-\frac{\delta\left(x, k l, \phi_{p}\right)}{\tau}+G(x)=0
$$

$\delta\left(x, k l, \phi_{p}\right)$ represents the excess minority carrier density in the base of the solar cell at the $\mathrm{x}$-position, dependent of the irradiation energy.

$D\left(k l, \phi_{p}\right)$ and $\tau$ are respectively the diffusion coefficient of the electrons in the base under irradiation and the lifetime of the excess minority carriers in in the base of the solar cell linked by the following Einstein relationship:

$$
\left[L\left(k l, \phi_{p}\right)\right]^{2}=\tau \times D\left(k l, \phi_{p}\right)
$$

with $L\left(k l, \phi_{p}\right)$ the diffusion length of the excess minority carriers in the base as a function of the irradiation energy flux $\left(\phi_{p}\right)$ and the damage coefficient intensity $(k l)$. It also represents the average distance traveled by the minority carriers before their recombination in the base under irradiation. It is related to the minority carrier's diffusion length before irradiation by the following empirical relation [25]:

$$
L\left(k l, \phi_{p}\right)=\frac{1}{\left(\frac{1}{L_{0}^{2}}+k l \cdot \phi_{p}\right)^{1 / 2}}
$$

where:

$L_{0}$ is diffusion length of the excess minority carriers in the base before irradiation,

$\phi_{p}$ is the irradiation energy flow,

$k l$ is the damage coefficient intensity.

D $G(x)$ is the excess minority carrier generation rate [49], given by:

$$
G(x)=n \cdot \sum_{i=1}^{3} a_{i} \mathrm{e}^{-b_{i} \cdot x}
$$

$n$ is the number of sun or level of illumination, indicating the concentration of incident light. 
The coefficients $a_{i}$ and $b_{i}$ take into account the tabulated values of solar radiation and the dependence of the absorption coefficient of silicon with the wavelength.

The resolution of the differential Equation (1) gives the expression of the excess minority carrier density in the base as:

$$
\delta\left(x, k l, \phi_{p}\right)=A \cdot \cosh \left[\frac{x}{L\left(k l, \phi_{p}\right)}\right]+B \cdot \sinh \left[\frac{x}{L\left(k l, \phi_{p}\right)}\right]+\sum K_{i} \cdot \mathrm{e}^{-b_{i} \cdot x}
$$

The expressions of, $A$ and $B$ are determined from the following boundary conditions:

a) At the junction emitter-base $(x=0)$

$$
\left.D\left(k l, \phi_{p}\right) \frac{\partial \delta\left(x, k l, \phi_{p}\right)}{\partial x}\right|_{x=0}=S_{f} \cdot \delta\left(0, k l, \phi_{p}\right)
$$

$S_{f}$ is the excess minority carrier recombination velocity at the junction and also indicates the operating point of the solar cell [30] [34] [35].

b) At the back side $(x=H)$

$$
\left.D\left(k l, \phi_{p}\right) \frac{\partial \delta\left(x, k l, \phi_{p}\right)}{\partial x}\right|_{x=H}=-S_{b} \cdot \delta\left(H, k l, \phi_{p}\right)
$$

$S_{b}$ is the excess minority carrier recombination velocity on the back side surface [29] [34] [35] [36]. It is the consequence of the electric field produced by the $\mathrm{p} / \mathrm{p}^{+}$junction and characterizes the behavior of the density of the charge carriers at this surface. It yields to send back towards the emitter-base junction, the minority carriers generated near the rear face, to then contribute to the photocurrent.

c) Photocurrent density

The expression of the photocurrent density is given by the relation:

$$
\begin{aligned}
\operatorname{Jph}\left(S f, H, k l, \varphi_{p}\right) & =q \cdot D\left(k l, \phi_{p}\right) \cdot\left[\frac{\partial \delta\left(S f, x, H, k l, \phi_{p}\right)}{\partial x}\right]_{x=0} \\
& =q \cdot D\left(k l, \phi_{p}\right)\left[\frac{B\left(S f, H, k l, \phi_{p}\right)}{L\left(k l, \phi_{p}\right)}+\sum_{i=1}^{3} K_{i} \cdot b_{i}\right]
\end{aligned}
$$

\section{Results and Discussions}

\subsection{Photocurrent Density}

Figure 2 represents the profiles of the photocurrent density as a function of the recombination velocity at the junction for different values of the irradiation energy and the optimum base thickness [46].

\subsection{Back Surface Recombination Velocity}

The $S b$ expression is obtained from the derivative of the photocurrent density for large $S f$ values [30] [34]. 


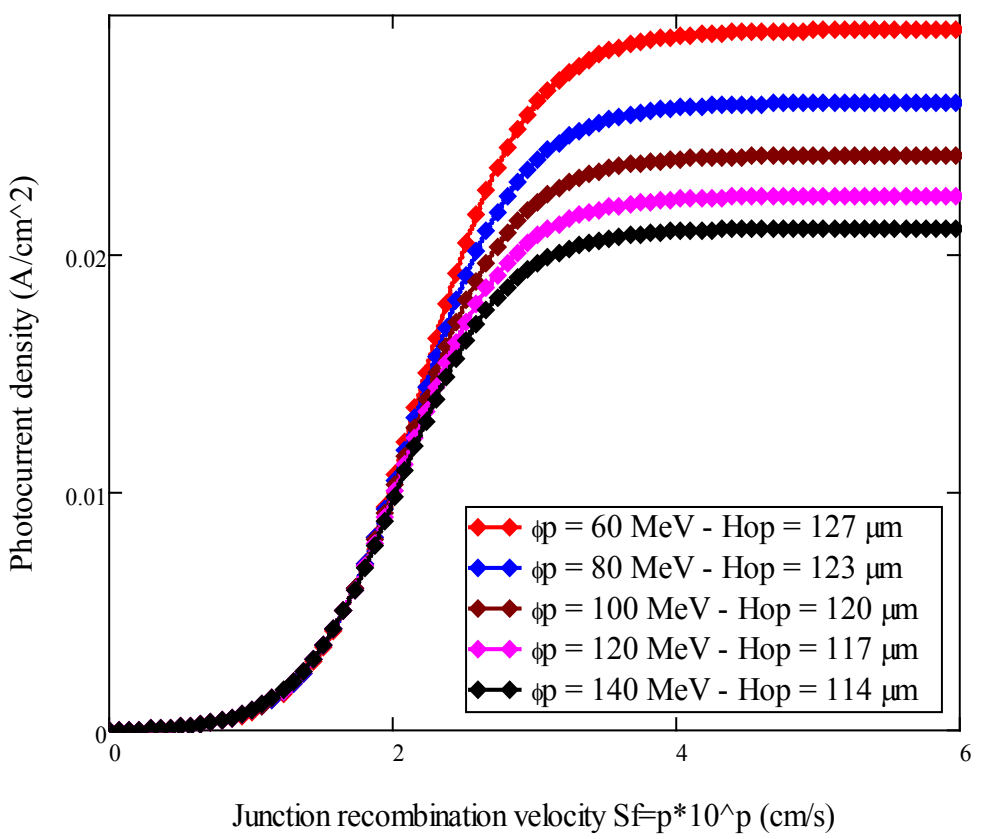

Figure 2. Photocurrent density as function the recombination velocity at junction for different irradiation energy flow and optimum base thickness with $k l=5 \mathrm{~cm}^{-2} / \mathrm{MeV}$.

$$
\left[\frac{\partial J p h\left(S f, k l, \phi_{p}\right)}{\partial S f}\right]_{S f \succ 5 \times 10^{5} \mathrm{~cm} \cdot \mathrm{s}^{-1}}=0
$$

The resolution of this equation yields to establish the following expressions of the excess minority carrier recombination velocity at the rear face, i.e. $\operatorname{SbO}\left(H, k l, \phi_{p}\right)$ and $\operatorname{Sbl}\left(H, k l, \phi_{p}\right)$ :

$$
\operatorname{Sb} 0\left(H, k l, \phi_{p}\right)=-\frac{D\left(k l, \phi_{p}\right)}{L\left(k l, \phi_{p}\right)} \times \tanh \left(\frac{H}{L\left(k l, \phi_{p}\right)}\right)
$$

It represents the intrinsic minority carrier's recombination velocity at the $\mathrm{p}-\mathrm{p}^{+}$ junction.

$$
\begin{aligned}
& \operatorname{Sbl}\left(H, k l, \phi_{p}\right) \\
& =\frac{D\left(k l, \phi_{p}\right)}{L\left(k l, \phi_{p}\right)} \cdot \sum_{i=1}^{3} \frac{L\left(k l, \phi_{p}\right) \cdot b_{i}\left(\mathrm{e}^{b_{i} \cdot H}-\cosh \left(\frac{H}{L\left(k l, \phi_{p}\right)}\right)\right)-\sinh \left(\frac{H}{L\left(k l, \phi_{p}\right)}\right)}{-L\left(k l, \phi_{p}\right) \cdot b_{i} \cdot \sinh \left(\frac{H}{L\left(k l, \phi_{p}\right)}\right)+\cosh \left(\frac{H}{L\left(k l, \phi_{p}\right)}\right)-\mathrm{e}^{b_{i} \cdot H}}
\end{aligned}
$$

It represents the recombination rate at the rear face influenced by the effect of the absorption of the light in the material through the coefficients $\left(b_{i}\right)$ and leads to a generation rate, for $L \gg H$.

Figure 3 represents the profile of the two expressions of the recombination velocity at the rear face $S b 0$ and $S b 1$ as function of the base thickness [46]. 


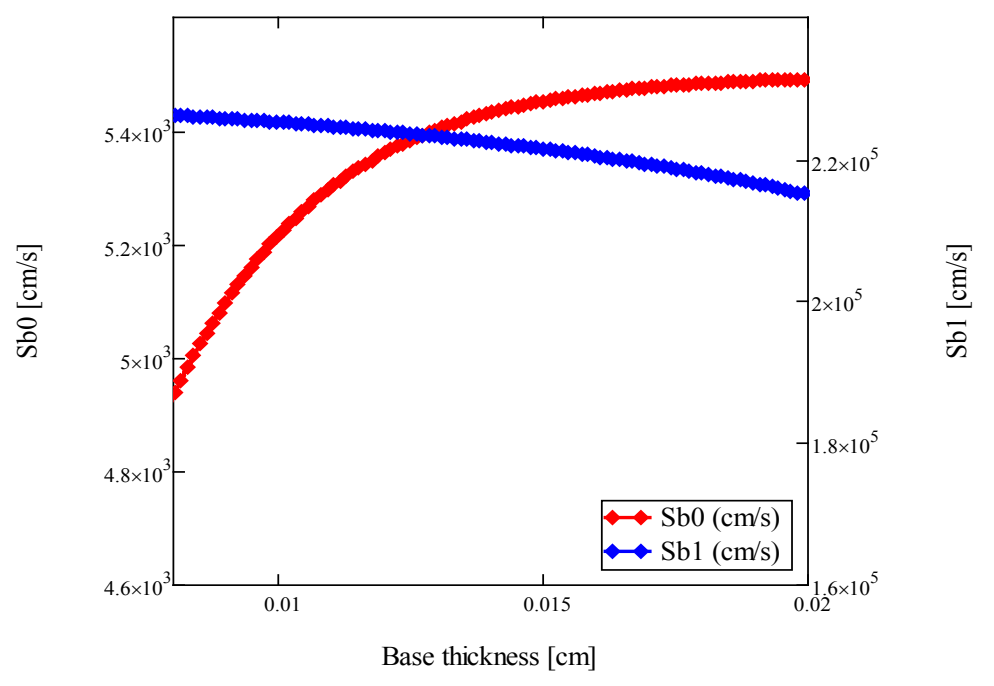

Figure 3. Back surface recombination velocity versus solar cell base thickness $\phi_{p}=140 \mathrm{MeV}$.

\subsection{Expression of Recombination Velocity Initiating the Short Circuit}

The recombination velocity of the charge carriers at the junction initiating the Sfcc short-circuit can be obtained from the different expressions of the photocurrent and the value of the short-circuit photocurrent [47] [48].

$$
J p h\left(S f, H, k l, \phi_{p}\right)-J p h_{S C}\left(H, k l, \phi_{p}\right)=0
$$

Equation (12) becomes replacing the photocurrent density by its expression:

$$
q \cdot D\left(k l, \phi_{p}\right) \cdot \frac{S f}{D\left(k l, \phi_{p}\right)}\left[A\left(S f, H, k l, \phi_{p}\right)+\sum_{i=1}^{3} K_{i}\right]-J p h_{S C}\left(H, k l, \phi_{p}\right)=0
$$

The resolution of Equation (13) yields to the mathematical expression of the minority carrier recombination velocity $S f c c\left(H, k l, \phi_{p}\right)$ initiating the short circuit, given as:

$$
\begin{aligned}
& \operatorname{Sfcc}\left(H, k l, \phi_{p}\right) \\
& =\left[\frac{\phi\left(k l, \phi_{p}\right) \cdot D^{2}\left(k l, \phi_{p}\right) \cdot \sinh \left(\frac{H}{L\left(k l, \phi_{p}\right)}\right)+\phi\left(k l, \phi_{p}\right) \cdot S_{b}\left(k l, \phi_{p}\right) \cdot L\left(k l, \phi_{p}\right) \cdot D\left(k l, \phi_{p}\right) \cdot \cosh \left(\frac{H}{L\left(k l, \phi_{p}\right)}\right)-\psi\left(k l, \phi_{p}\right)}{-\left(\left(\phi\left(k l, \phi_{p}\right) \cdot L^{2}\left(k l, \phi_{p}\right) \cdot S_{b}\left(k l, \phi_{p}\right) \cdot \sinh \left(\frac{H}{L\left(k l, \phi_{p}\right)}\right)\right)-\phi\left(k l, \phi_{p}\right) \cdot L\left(k l, \phi_{p}\right) \cdot D\left(k l, \phi_{p}\right) \cdot \cosh \left(\frac{H}{L\left(k l, \phi_{p}\right)}\right)+\gamma\left(k l, \phi_{p}\right)\right)}\right]
\end{aligned}
$$

$$
\begin{gathered}
\psi\left(k l, \phi_{p}\right)=L\left(k l, \phi_{p}\right) \cdot D^{2}\left(k l, \phi_{p}\right) \cdot \sum_{i=1}^{3}\left(K_{1} \cdot b_{i}\right) \\
\gamma\left(k l, \phi_{p}\right)=L\left(k l, \phi_{p}\right) \cdot D\left(k l, \phi_{p}\right) \cdot X\left(H, k l, \phi_{p}\right) \cdot \sum_{i=1}^{3}\left(K_{i}\right) \\
-L\left(k l, \phi_{p}\right) \cdot \sum_{i=1}^{3}\left(K_{i} \cdot \alpha\left(k l, \phi_{p}\right)\right)
\end{gathered}
$$




$$
\begin{array}{r}
\alpha\left(k l, \phi_{p}\right)=L\left(k l, \phi_{p}\right)\left[S_{b}\left(k l, \phi_{p}\right)-D\left(k l, \phi_{p}\right) b_{i}\right]\left(\mathrm{e}^{-b_{i} H}\right) \\
\phi\left(k l, \phi_{p}\right)=L\left(k l, \phi_{p}\right)\left[\frac{J p h_{S C}\left(H, k l, \phi_{p}\right)}{q \cdot D\left(k l, \phi_{p}\right)}-\sum_{i=1}^{3}\left(K_{i} \cdot b_{i}\right)\right] \\
X\left(H, k l, \phi_{p}\right)=D\left(k l, \phi_{p}\right) \sinh \left(\frac{H}{L\left(k l, \phi_{p}\right)}\right) \\
+L\left(k l, \phi_{p}\right) S_{b}\left(k l, \phi_{p}\right) \cosh \left(\frac{H}{L\left(k l, \phi_{p}\right)}\right)
\end{array}
$$

\subsection{Shunt Resistance}

\subsubsection{Phototension}

The expression of the phototension is obtained using the well-known Boltzmann relation as:

$$
\operatorname{Vph}\left(S f, H, k l, \phi_{p}\right)=\frac{K b \times T}{q} \cdot \ln \left(\frac{N b}{n_{i}^{2}} \cdot \delta\left(0, H, k l, \phi_{p}\right)+1\right)
$$

where, $K b$ is the Boltzmann constant, $q$ is the elementary charge of the electron and $T$ is the temperature. $N b$ is the solar cell base doping rate, $n_{i}$ is the intrinsic density of minority charge carriers.

\subsubsection{Experimental Shunt Resistance}

Figure 4 represents the well-known $(J s c(S f)-V p h(S f))$ electric characteristic of the solar cell under illumination.

By applying the law of nodes and that of the meshes to the circuit of the Figure 5 we obtain the expression of the shunt resistance expressed as:

$$
R s h\left(S f, H, k l, \phi_{p}\right)=\frac{\operatorname{Vph}\left(S f, H, k l, \phi_{p}\right)}{J p h_{s c}\left(H, k l, \phi_{p}\right)-J p h\left(S f, H, k l, \phi_{p}\right)}
$$

Figure 6 gives the profile of the calibrated curve of the expression of the shunt resistance as a function of excess minority carrier recombination velocity at the junction, for different irradiation energy.

\subsubsection{Experimental Determination Technique of Shunt Resistance}

Figure 7 gives the technique of experimental determination of the shunt resistor, from the surface recombination velocity at the junction initiating the short circuit (Sfsc) in the solar cell, which intercepts the calibration curve to give an ordinate equal to the experimental shunt resistance (Rshexp) [47] [48].

Table 1 represents the values of the recombination velocity Sfsc initiating the short circuit in the solar cell, obtained for different irradiation energy, damage coefficient and yield to the shunt resistors Rshexp.

Figure 8 shows a decreasing plot of the shunt resistance reverse Rshexp versus irradiation energy for given intensity.

The equation obtained from the shunt resistance as a function of the irradiation energy is given by the following relation: 


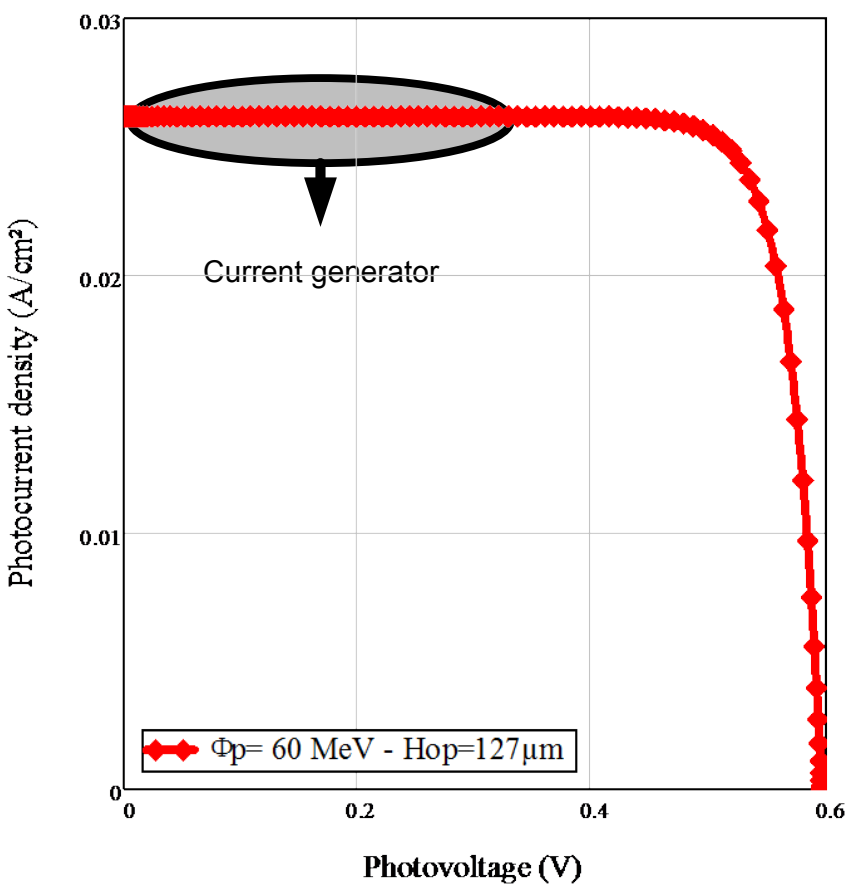

Figure 4. Photocurrent density as a function of photovoltage.

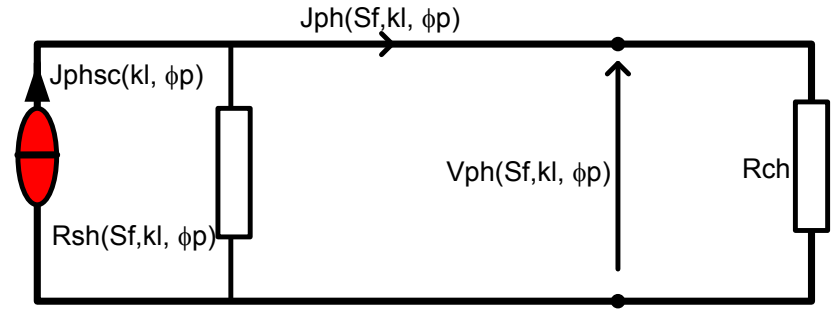

Figure 5. Equivalent electrical circuit of the short circuit.

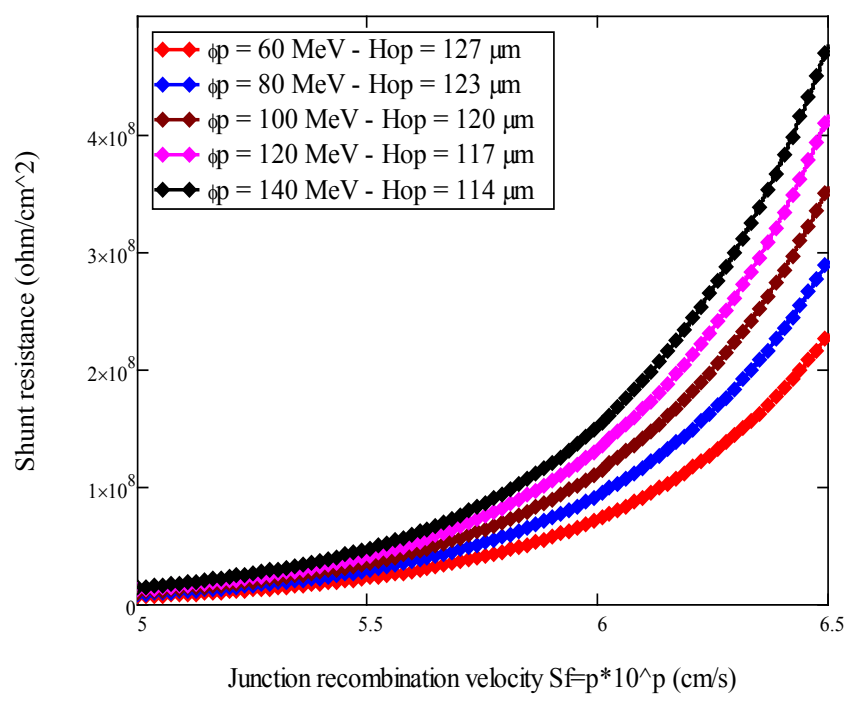

Figure 6. Calibrated shunt resistance curve versus junction surface recombination velocity for different irradiation energy corresponding the optimum base thickness with $\mathrm{kl}=5 \mathrm{~cm}^{-2} / \mathrm{MeV}$. 


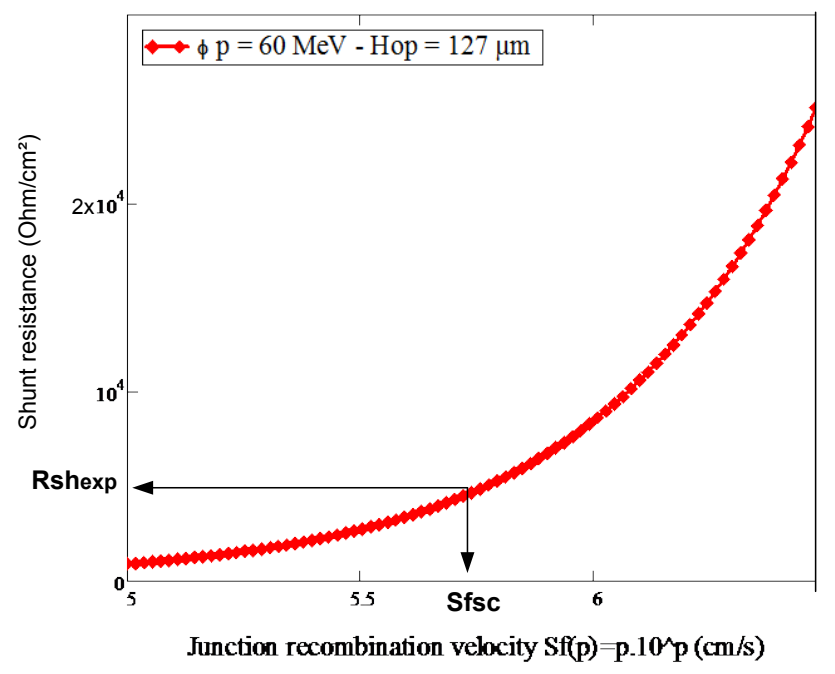

Figure 7. Calibrated curve for the determination of the experimental shunt resistance.

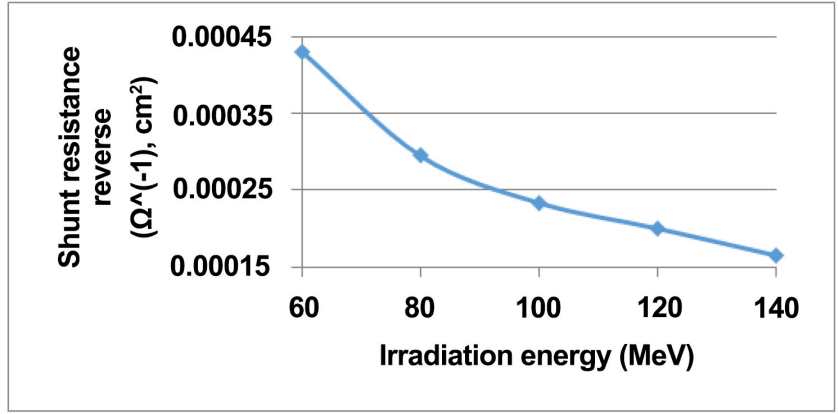

Figure 8. Experimental shunt resistance reverse versus irradiation energy.

Table 1. Rshexp values for different irradiation energy with $k l=5 \mathrm{~cm}^{-2} / \mathrm{MeV}$.

\begin{tabular}{cc}
\hline Irradiation energy $(\mathrm{MeV})$ & $R s h_{\text {exp }}\left(\Omega / \mathrm{cm}^{2}\right)$ \\
\hline 60 & 2321.4 \\
80 & 3392.9 \\
100 & 4285.7 \\
120 & 5000 \\
140 & 6071.4 \\
\hline
\end{tabular}

$$
\frac{1}{R s h_{\text {exp }}}=a \times \phi_{p}^{2}-b \times \phi_{p}+c
$$

With: $a=4 \times 10^{-8} \Omega^{-1} \cdot \mathrm{cm}^{2}, b=10^{-5} \Omega^{-1} \cdot \mathrm{cm}^{2}$ and $c=0.001 \Omega^{-1} \cdot \mathrm{cm}^{2}$.

Among previous work on solar cells that have undergone, irradiation of charged particles and their effects on physical mechanisms influencing performance [42] [43], our work proposes a mathematical modeling of the results of shunt resistance based on the optimum thickness specific to each flow and in- 
tensity of irradiation. This result allows the choice of the thickness of the solar cell in the process of its manufacture, in anticipation of the conditions of its operation.

\section{Conclusions}

In this work, a technique has been proposed for determining the shunt resistance from the calibration curves as a function of the recombination velocity at the junction initiating the short circuit under variation the irradiation energy flow and the optimum base thickness of silicon solar cell.

The graphical resolution of the rear faces recombination velocity at the intrinsic or electronic and that dependent on the absorption coefficient bi, yields to determinate the optimum base thickness under irradiation energy flow. The shunt resistance increases with the irradiation energy flow and is modeled through a mathematical relationship, taking into account the useful optimum thickness adapted to the conditions of irradiation by charged particles.

\section{Conflicts of Interest}

The authors declare no conflicts of interest regarding the publication of this paper.

\section{References}

[1] Bertrand, D., Manuel, S., Pirot, M., Kaminski-Cachopo, A. and Veschetti, Y. (2017) Modelling of Edge Losses in Al-BSF Silicon Solar Cells. IEEE Journal of Photovoltaic, 7, 78-84. https://doi.org/10.1109/JPHOTOV.2016.2618603

[2] Mohammad, S.N. (1987) An Alternative Method for the Performance Analysis of Silicon Solar Cells. Journal of Applied Physics, 61, 767. https://doi.org/10.1063/1.338230

[3] Yadav, P., Pandey, K., Tripathi, B., Kumar, C.M., Srivastava, S.K., Singh, P.K. and Kumar, M. (2015) An Effective Way to Analyze the Performance Limiting Parameters of a Poly-Crystalline Silicon Solar Cell Fabricated in the Production Line. Solar Energy, 122, 1-10. https://doi.org/10.1016/j.solener.2015.08.005

[4] Green, M.A. (1995) Silicon Solar Cells Advanced Principles \& Practice Printed by Bridge Printer Pty. Ltd. 29-35 Dunning Avenue, Roseberry, Centre for Photovoltaic Devices and Systems.

[5] Lago-Aurrekoetxea, R.M., Del Can, C., Izo, Pou, I. and Luque, A. (2001) Fabrication Process for Thin Silicon Solar Cells. Proceeding 17 th European PVSEC, Munich, 1519-1522.

[6] Bowden and Rohatgi, A. (2001) Rapid and Accurate Determination of Series Resistance and Fill Factor Losses in Industrial Silicon Solar Cells. Proceeding of 17 th European PVSEC, Munich, 1802-1806.

[7] Huljié, E.H., Ludemann, R. and Willeke, G. (2001) Large Area Crystalline Silicon Solar Cells with Pad Printed Front Side Metallization. Proceeding of 17 th European PVSEC, Munich, 1582-1585.

[8] Sow, O., Zerbo, I., Mbodji, S., Ngom, M.I., Diouf, M.S. and Sissoko, G. (2012) Silicon Solar Cell under Electromagnetic Waves in Steady State: Electrical Parameters Determination Using the I-V and P-V Characteristics. International Journal of 
Science, Environment and Technology, 1, 230-246.

[9] Dione, B., Sow, O., Wade, M., Ibrahima, L.Y., Mbodji, S. and Sissoko, G. (2016) Experimental Processus for Acquisition Automatic Features of I-V Properties and Temperature of the Solar Panel by Changing the Operating Point. Circuits and Systems, 7, 3984-4000. http://www.scirp.org/journal/cs https://doi.org/10.4236/cs.2016.711330

[10] Bashahu, M. and Habyarimana, A. (1995) Review and Test of Methods for Determination of the Solar Cell Series Resistance. Renewable Energy, 6, 127-138. https://doi.org/10.1016/0960-1481(94)E0021-V

[11] El-Adawi, M.K. and Al-Nuaim, I.A. (2002) A Method to Determine the Solar Cell Series Resistance from a Single I-V Characteristic Curve Considering Its Shunt Resistance: New Approach. Vacuum, 64, 33-36. https://doi.org/10.1016/S0042-207X(01)00370-0

[12] Bouzidi, K., Chegaar, M. and Bouhemadou, A. (2007) Solar Cells Parameters Evaluation Considering the Series and Shunt Resistance. Solar Energy Materials \& Solar Cells, 91, 1647-1651. https://doi.org/10.1016/j.solmat.2007.05.019

[13] Singh, K.J., Kho, K.L.R., Singh, S.J., Devi, Y.C., Singh, N.B. and Sarkar, S.K. (2014) Artificial Neural Network Approach for More Accurate Solar Cell Electrical Circuit Model. International Journal on Computational Sciences \& Applications, 4, 101-116. https://doi.org/10.5121/ijcsa.2014.4310

[14] Ghani, F. and Duke, M. (2011) Numerical Determination of Parasitic Resistances of a Solar Cell Using the Lambert W-Function. Solar Energy, 85, 2386-2394.

https://doi.org/10.1016/j.solener.2011.07.001

[15] Dione, M.M., Diallo, H.L., Wade, M., Ly, I., Thiame, M., Toure, F., Camara, A.G., Dieme, N., Bako, Z.N., Mbodji, S., Barro, F.I. and Sissoko, G. (2011) Determination of the Shunt and Series Resistances of a Vertical Multijunction Solar Cell under Constant Multispectral Light. Proceedings of the 26th European Photovoltaic Solar Energy Conference, 250-254. https://www.eupvsec-proceedings.com/

[16] Scofield, J.H. (1995) Effects of Series Resistance and Inductance on Solar Cell Admittance Measurements. Solar Energy Materials and Solar Cells, 37, 217-233, https://doi.org/10.1016/0927-0248(95)00016-X

[17] Chenvidhya, D., Kirtikara, K. and Jivacate, C. (2003) A New Characterization Method for Solar Cell Dynamic Impedance. Solar Energy Materials and Solar Cells, 80, 459-464. https://doi.org/10.1016/j.solmat.2003.06.011

[18] Suresh, M.S. (1996) Measurement of Solar Cell Parameters Using Impedance Spectroscopy. Solar Energy Materials and Solar Cells, 43, 21-28. https://doi.org/10.1016/0927-0248(95)00153-0

[19] Gôkan, S., Thiam, N., Ndiaye, M., Diao, A., Mbow, B. and Sissoko, G. (2013) Influence of Illumination Wavelength on the Electrical Parameters of a Vertical Junction Silicon Solar Cell under Frequency Modulation. International Journal of Electrical Engineering, 1, 23-28. http://www.ipasj.org/IIJEE/IIJEE.htm

[20] Wu, C.Y. and Shen, W.Z. (1979) The Open-Circuit Voltage of Back-Surface-Field (BSF) $p$ - $n$ Junction Solar Cells in Concentrated Sunlight. Solid-State Electronics, 23, 209-216. https://doi.org/10.1016/0038-1101(80)90004-0

[21] Diatta, I., Diouf, M.S., Thiame, M., Traore, Y., Diasse, O. and Sissoko, G. (2017) Influence of Temperature on Silicon Solar Cell Shunt Resistance under Monochromatic Illumination. Journal of Scientific and Engineering Research, 4, 30-39. http://www.jsaer.com

[22] Zoungrana, M., Thiame, M., Dioum, A., Raguilnaba, S. and Sissoko, G. (2007) 3D 
Study of a Bifacial Silicon Solar Cell under Intense Light Concentration and under External Constant Magnetic Field: Recombination and Electrical Parameters Determination. Proceedings of the 22nd European Photovoltaic Solar Energy Conference and Exhibition, 447-453.

[23] Diao, A., Thiam, N., Zoungrana, M., Sahin, G., Ndiaye, M. and Sissoko, G. (2014) Diffusion Coefficient in Silicon Solar Cell with Applied Magnetic Field and under Frequency: Electric Equivalent Circuits. World Journal of Condensed Matter Physics, 4, 84-92. https://doi.org/10.4236/wjcmp.2014.42013

[24] Ould El Moujtaba, M.A., Ndiaye, M., Diao, A., Thiam, M., Barro, I.F. and Sissoko, G. (2012) Theoretical Study of Influence of Irradiation on a Silicon Solar Cell under Multispectral Illumination. Research Journal of Applied Sciences Engineering and Technology, 23, 5068-5073.

[25] Ba, M.L., Diallo, H.L., Ba, H.Y., Traore, Y., Diatta, I., Diouf, M.S., Wade, M. and Sissoko, G. (2018) Irradiation Energy Effect on a Silicon Solar Cell: Maximum Power Point Determination. Journal of Modern Physics, 9, 2141-2155. https://doi.org/10.4236/jmp.2018.912135

[26] Diouf, S., Ndiaye, M., Thiam, N., Traore, Y., Ba, M.L., Diatta, I., Diouf, M.S., Mballo, O., Thiam, A., Ly, I. and Sissoko, G. (2019) Influence of Temperature and Frequency on Minority Carrier Diffusion Coefficient in a Silicon Solar Cell under Magnetic Field. Energy and Power Engineering, 11, 355-361. https://doi.org/10.4236/epe.2019.1110023

[27] Diop, M., Ba, H., Thiam, N., Diatta, I., Traore, Y., Ba, M., Sow, E., Mballo, O. and Sissoko, G. (2019) Surface Recombination Concept as Applied to Determinate Silicon Solar Cell Base Optimum Thickness with Doping Level Effect. World Journal of Condensed Matter Physics, 9, 102-111. https://doi.org/10.4236/wjcmp.2019.94008

[28] Kosso, A.M.M., Thiame, M., Traore, Y., Diatta, I., Ndiaye, M., Habiboullah, L., Ly, I. and Sissoko, G. (2018) 3D Study of a Silicon Solar Cell under Constant Monochromatic Illumination: Influence of Both, Temperature and Magnetic Field. Journal of Scientific and Engineering Research, 5, 259-269.

[29] Fossum, J.G., Burgess, E.L. and Lindholm, F.A. (1978) Silicon Solar Cell Designs Based on Physical Behavior in Concentrated Sunlight. Solid-State Electronics, 27, 729-737. https://doi.org/10.1016/0038-1101(78)90005-9

[30] Diallo, H.L., Maiga, A.S., Wereme, A. and Sissoko, G. (2008) New Approach of Both Junction and Back Surface Recombination Velocities in a 3D Modelling Study of a Polycrystalline Silicon Solar Cell. The European Physical Journal Applied Physics, 42, 193-211. https://doi.org/10.1051/epjap:2008085

[31] Barro, F.I., Gaye, S., Deme, M., Diallo, H.L., Samb, M.L., Samoura, A.M., Mbodji, S. and Sissoko, G. (2008) Influence of Grain Size and Grain Boundary Recombination Velocity on the Series and Shunt Resistance of a Poly-Crystalline Silicon Solar Cell. Proceedings of the 23rd European Photovoltaic Solar Energy Conference, 612-615.

[32] Oualid, J., Bonfils, M., Crest, J.P., Mathian, G., Amzil, H., Dugas, J., Zehaf, M. and Martinuzzi, S. (1982) Photocurrent and Diffusion Lengths at the Vicinity of Grain Boundaries (g.b.) in N and P-Type Polysilicon. Evaluation of the g.b. Recombination Velocity. Revue de Physique Appliquée, 17, 119-124. https://doi.org/10.1051/rphysap:01982001703011900

[33] De Visschere, P. (1986) Surface Recombination Velocity: A Useful Concept? Solid-State Electronics, 29, 1161-1165. https://doi.org/10.1016/0038-1101(86)90059-6

[34] Sissoko, G., Museruka, C., Corréa, A., Gaye, I. and Ndiaye, A.L. (1996) Light Spectral Effect on Recombination Parameters of Silicon Solar Cell. World Renewable 
Energy Congress, Pergamon, Part III, 1487-1490.

[35] Sissoko, G., Nanema, E., Correa, A., Adj, M., Ndiaye, A.L. and Diarra, M.N. (1998) Recombination Parameters Measurement in Double Sided Surface Field Solar Cell. Proceedings of World Renewable Energy Conference, Florence, 1856-1859.

[36] Rose, B.H. and Weaver, H.T. (1983) Determination of Effective Surface Recombination Velocity and Minority-Carrier Lifetime in High-Efficiency Si Solar Cells. Journal of Applied Physics, 54, 238-247. https://doi.org/10.1063/1.331693

[37] Bocande, Y.L., Correa, A., Gaye, I., Sow, M.L. and Sissoko, G. (1994) Bulk and Surfaces Parameters Determination in High Efficiency Si Solar Cells. Proceedings of the World Renewable Energy Congress, Vol. 3, 1698-1700.

[38] Diasse, B.O., Diao, A., Wade, M., Diouf, M.S., Diatta, I., Mane, R., Traore, Y. and Sissoko, G. (2018) Back Surface Recombination Velocity Modeling in White Biased Silicon Solar Cell under Steady State. World Journal of Condensed Matter Physics, 9, 189-201. https://doi.org/10.4236/jmp.2018.92012

[39] Ba, F., Seibou, B., Wade, M., Diouf, M.S., Ly, I. and Sissoko, G. (2016) Equivalent Electric Model of the Junction Recombination Velocity Limiting the Open Circuit of a Vertical Parallel Junction Solar Cell under Frequency Modulation. International Journal of Electronics \& Communication, 4, 1-11.

[40] Ndiaye, E.H., Sahin, G., Thiam, A., Dieng, M., Diallo, H.L., Ndiaye, M. and Sissoko, G. (2015) Study of the Intrinsic Recombination Velocity at the Junction of Silicon Solar under Frequency Modulation and Irradiation. Journal of Applied Mathematics and Physics, 3, 1522-1535. http://www.scirp.org/journal/jamp https://doi.org/10.4236/jamp.2015.311177

[41] Diallo, M.M., Tamba, S., Seibou, B., Cheikh, M.L.O., Diatta, I., Ndiaye, E.H., Traore, Y., Sarr, C.T. and Sissoko, G. (2017) Impact of Irradiation on the Surface Recombination Velocity of a Back Side Monochromatic Illuminated Bifacial Silicon Solar Cell under Frequency Modulation. Journal of Scientific and Engineering Research, 4, 29-40.

[42] Ohshima, T., Sumita, T., Imaizumi, M., Kawakita, S., Shimazaki, K., Kuwajima, S., Ohi, A. and Itoh, H. (2005) Evaluation of the Electrical Characteristics of III-V Compounds Solar Cells Irradiated with Protons at Low Temperatures. Proceedings of the 31 st IEEE Photovoltaic Specialists Conference, Lake Buena Vista, 3-7 January 2005, 806-809. https://doi.org/10.1109/PVSC.2005.1488255

[43] Shin, G.H., et al. (2008) Radiation Effect Test for Single-Crystalline and Polycrystalline Silicon Solar Cells. Journal of the Korean Physical Society, 52, 843-847. http://hdl.handle.net/10203/89159 https://doi.org/10.3938/jkps.52.843

[44] Honma, N. and Munakata, C. (1987) Sample Thickness Dependence of Minority Carrier Lifetimes Measured Using an ac Photovoltaic Method. Japanese Journal of Applied Physics, 26, 2033-2036. https://doi.org/10.1143/JJAP.26.2033

[45] Demesmaeker, E., Symons, J., Nijs, J. and Mertens, R. (1991) The Influence of Surface Recombination on the Limiting Efficiency and Optimum Thickness of Silicon Solar Cells. 10 th European Photovoltaic Solar Energy Conference, Lisbon, 66-67. https://doi.org/10.1007/978-94-011-3622-8_17

[46] Ba, M.L, Thiam, N., Thiame, M., Traore, Y., Diop, M., Ba, M., Sarr, C., Wade, M. and Sissoko, G. (2019) Base Thickness Optimization of a (n+-p-p+) Silicon Solar Cell in Static Mode under Irradiation of Charged Particles. Journal of Electromagnetic Analysis and Applications, 11, 173-185. https://doi.org/10.4236/jemaa.2019.1110012 
[47] Ly, I., Ndiaye, M., Wade, M., Thiam, N., Gueye, S. and Sissoko, G. (2013) Concept of Recombination Velocity Sfcc at the Junction of a Bifacial Silicon Solar Cell, in Steady State, Initiating the Short-Circuit Condition. Research Journal of Applied Sciences, Engineering and Technology, 5, 203-208. https://doi.org/10.19026/rjaset.5.5105

[48] Diouf, M.S., Ly, I., Wade, M., Diatta, I., Traore, Y., Ndiaye, M. and Sissoko, G. (2016) The Temperature Effect on the Recombination Velocity at the Junction Initiating the Short-Circuit Condition (Sfcc) of a Silicon Solar Cell under External Electric Field. Journal of Scientific and Engineering Research, 3, 410-420.

[49] Furlan, J. and Amon, S. (1985) Approximation of the Carrier Generation Rate in Illuminated Silicon. Solid-State Electronics, 28, 1241-1243.

https://doi.org/10.1016/0038-1101(85)90048-6 